J. Perinat. Med. 10 (1982) 226

\section{Continuous measurement of blood gas tensions in the fetal guinea pig by mass spectrometry}

\author{
J $\phi$ rgen Gronlund, Anthony M. Carter
}

Department of Physiology, University of Odense, Denmark

\section{Introduction}

Recent progress in the measurement of intravascular blood gas tensions by mass spectrometry [8, $13]$ is of potential interest in the study of placental gas exchange, because the mass spectrometer allows continuous measurement of both $\mathrm{pO}_{2}$ and $\mathrm{pCO}_{2}$. The determination of blood gases by conventional techniques, which mostly require blood sampling, has contributed significantly to the investigation of placental gas exchange $[6,11,16]$. Mass spectrometry, however, can give important additional information about the kinetics of transplacental gas exchange.

The guinea pig is an important model in placental research, because its discoid, haemomonochorial placenta resembles that of man [7]. Hitherto, the study of placental gas exchange in this species has been limited, because conventional methods of gas analysis require blood samples that are large in relation to the blood volume of the fetus. In the present study, we have investigated the feasibility of monitoring the blood gases of fetal guinea pigs by mass spectrometry, using an intravascular probe developed for this purpose [13]. Simultaneous and continuous measurements of $\mathrm{pO}_{2}$ and $\mathrm{pCO}_{2}$ in the right atrium of the fetuses were made before, during and after an acute change in maternal placental blood flow provoked by an infusion of nor. adrenaline.

\section{Curriculum vitae}

JQRGEN GRQNLUND, research scholar at the University of Odense, was born in 1953. He read medicine at Odense from 1972-1981, and received a university award for his work on the construction of catheters for the measurement of blood gases by mass spectrometry. Apart from the study of placental gas exchange, his main interest is the determination

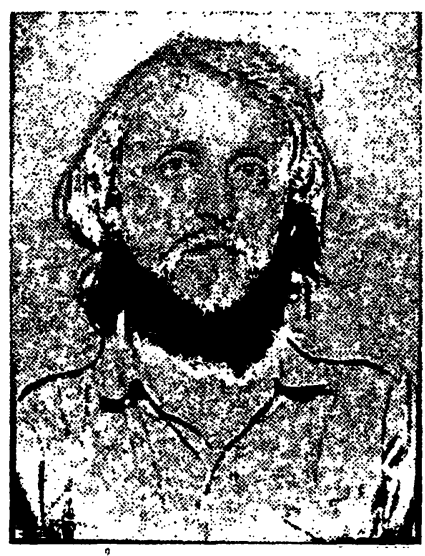
of cardiac output by mass spectroscopic analysis of respiratory gases.

\section{Materials and methods}

\subsection{Measurement of gas tensions}

Gas tensions were measured with a mass spectrometer (MICROMASS SX 200, VG ANALYSIS, Winsford, England) via a blood gas catheter which is described in detail elsewhere [13]. In essence, it is a stainless steel tube, the lumen of which is connected to the high vacuum chamber of the mass spectrometer. The catheter tip is covered by a $20 \mu \mathrm{m}$ polyethylene membrane supported by a 
porous sintered bronze plug (Fig. 1). When the membrane is in contact with the blood, oxygen and carbon dioxide diffuse through it and are drawn towards the vacuum chamber. The mass spectrometer signal due to diffusive flux is directly proportional to the partial pressure of each gas at the membrane surface. The $63 \%$ response time of the system is less than seven seconds for both oxygen and carbon dioxide.

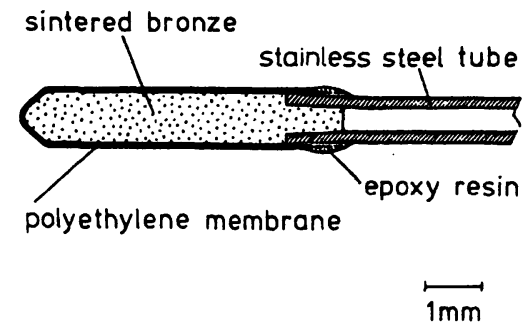

Fig. 1. Design of catheter used to measure gas tensions in fetal blood.

The relation between the mass spectrometer response and the tensions of oxygen and carbon dioxide in blood was determined in five calibration experiments. The blood gas catheter was inserted in the ascending aorta of adult guinea pigs, and gas tensions were measured with a microsystem blood gas analyzer (BMS Mk 2, RADiOMETER, Copenhagen, 'Denmark) in blood samples obtained from a femoral artery. Artificial ventilation was given through a tracheal cannula and arterial $\mathrm{pO}_{2}$ and $\mathrm{pCO}_{2}$ were manipulated by varying the respiratory frequency. The animals were curarized, but the anaesthetic regimen was otherwise identical to that in experiments without muscle relaxants.

\subsection{Experimental procedures}

Nine guinea pigs of outbred stock (Ssc:AL), mated in our laboratories, were studied on the 64 th67 th day of gestation. Maternal body weight was 930-1085 g.

The animals were anaesthetized with pentobarbitone sodium $(25 \mathrm{mg} / \mathrm{kg}$ I.P.) after premedication with atropine $(0.05 \mathrm{mg})$ and diazepam $(1 \mathrm{mg} / \mathrm{kg})$. Oxygen was added to the inspired air but respiration was not otherwise assisted. Rectal temperature was maintained at $38{ }^{\circ} \mathrm{C}$ with the aid of a heating pad. To allow determination of maternal cardiac output and placental blood flow, a catheter for microsphere injection was passed from a carotid artery to the left ventricle and a femoral artery was catheterized for the withdrawal of blood samples. Catheters were also placed in the opposite femoral artery and a jugular vein to enable registration of arterial blood pressure and for the subsequent infusion of noradrenaline. A detailed description of these procedures has been given elsewhere [15].

The abdomen was opened by a midline incision and the uterus, wrapped in plastic foil, was placed on a thermostatted table, as recommended by KASTENDIECK and Moll [12]. The umbilical cord of one fetus was exposed through an incision in the uterine wall, and a sample of umbilical venous blood was obtained for the determination of blood gas tensions and acid-base status. The head and neck of a second fetus was then exposed, and the blood gas catheter inserted by a cutdown in the right jugular vein. The tip of the catheter was advanced $20-25 \mathrm{~mm}$. Fetal blood gas tensions were measured throughout the rest of the experiment by mass spectrometry. The fetus and the uterus were warmed from above by a heating lamp. Heparinized samples of maternal blood were withdrawn intermittently and analyzed for $\mathrm{pH}$, $\mathrm{pO}_{2}$ and $\mathrm{pCO}_{2}$ with a microsystem blood gas analyzer (BMS Mk 2, RADIOMETER, Copenhagen, Denmark).

Maternal placental blood flow and cardiac output were measured twice, using microspheres ( $3 \mathrm{M} \mathrm{Co}$., St Paul, Minnesota) labelled with $\mathrm{Ce}^{141}$ and $\mathrm{Sr}^{85}$ (mean diameters $15.2 \pm 0.7$ and $15.4 \pm 0.8 \mu \mathrm{m}$ ). The first measurement served as a control for the second determination, which was made during the intravenous infusion of noradrenaline bitartrate $(10-20 \mu \mathrm{g} / \mathrm{min} / \mathrm{kg})$. On each occasion $6 \cdot 10^{5}-$ $7 \cdot 10^{5}$ microspheres were injected in the left ventricle whilst a reference sample of blood was withdrawn at a constant rate from the femoral artery [15].

At the conclusion of the experiment, the fetal thorax was opened to ascertain the position of the blood gas catheter tip. The site of microsphere injection was confirmed by dissection of the maternal heart. The placentas and the uterus, 
kidneys, lungs and brain of the mother were removed and weighed. The radioactivity in the organs and in the reference samples of blood was measured in a gamma spectrometer with a three inch crystal and a multichannel analyzer. Cardiac output and organ blood flows were derived as earlier described [15]. Two experiments were rejected because a comparison of right and left renal perfusion suggested uneven distribution of the microspheres. Placement of the blood gas catheter in the right atrium was successful in five of the remaining experiments.

\section{Results}

After placement of a blood gas catheter in the right atrium of the fetus, mean maternal placental blood flow was $1.18 \pm 0.05 \mathrm{ml} / \mathrm{min} / \mathrm{g}$. A reduction in blood flow of $25-95 \%$ was achieved by varying the rate and duration of the noradrenaline infusion (Tab. I). Blood gas tensions in the right atrium of the fetus before and after the flow reduction are shown in Tab. I. There was a decrease in $\mathrm{pO}_{2}$, corresponding in extent to the change in blood flow, and a consistent rise in $\mathrm{pCO}_{2}$.

The continuous and simultaneous measurement of the two blood gases revealed a characteristic difference in the time course of their responses to an acute reduction in placental perfusion. Thus $\mathrm{pO}_{2}$ responded quite rapidly and tended to find a new level, whereas $\mathrm{pCO}_{2}$ rose gradually throughout the period of noradrenaline infusion (Fig. 2). Fifteen minutes after the end of the infusion, $\mathrm{pO}_{2}$ had returned to $12.6 \pm 2.1$ torr, whereas $\mathrm{pCO}_{2}$ was still elevated at $67.1 \pm 4.8$ torr.
To provide a basis for evaluation of the preparation, umbilical venous blood was taken from another fetus in the litter, and analyzed by conventional means. Mean values were: $\mathrm{pO}_{2} 24.5 \pm$ 1.4 torr, $\mathrm{pCO}_{2} 41.7 \pm 1.2$ torr, $\mathrm{pH} 7.268 \pm 0.041$ and base deficit $6.7 \pm 2.1 \mathrm{mmoles} / 1$. The status of the doe (Tab. II) resembled that of late pregnant guinea pigs in which maternal placental blood flow was measured without laparotomy or manipulation of the fetus [14].

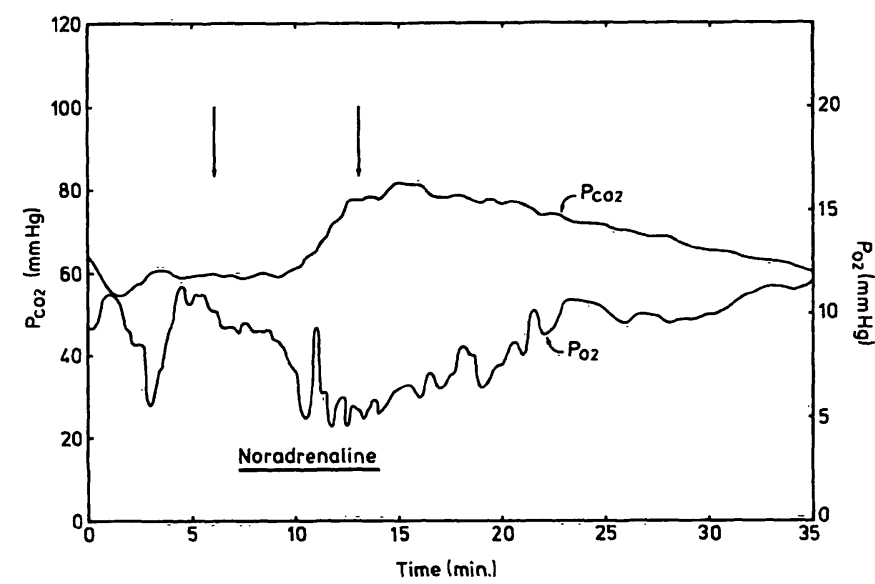

Fig. 2. Right atrial $\mathrm{pO}_{2}$ and $\mathrm{pCO}_{2}$ recorded from a guinea pig fetus before, during and after infusion of noradrenaline in a maternal vein. During the noradrenaline infusion, there was a continuous rise in $\mathrm{pCO}_{2}$ and a fall in $\mathrm{pO}_{2}$, concomitant with a reduction in maternal placental blood flow from $1.06 \mathrm{ml} / \mathrm{min} / \mathrm{g}$ (first arrow) to $0.29 \mathrm{ml} /$ $\mathrm{min} / \mathrm{g}$ (second arrow). Fluctuations in the pre-infusion period may reflect spontaneous variations in placental blood supply.

\section{Discussion}

Important information on the kinetics of placental gas exchange has been obtained through the continuous measurement of fetal oxygen tensions

Tab. I. Reduction in maternal placental blood flow during noradrenaline infusion and its effect on fetal blood gases, measured from a catheter in the right atrium.

\begin{tabular}{|c|c|c|c|c|c|c|}
\hline & \multicolumn{2}{|c|}{$\begin{array}{l}\text { Placental blood flow } \\
\mathrm{ml} / \mathrm{min} / \mathrm{g}\end{array}$} & \multicolumn{2}{|c|}{$\begin{array}{l}\mathrm{pCO}_{2}, \text { right atrium } \\
\text { torr }\end{array}$} & \multicolumn{2}{|c|}{$\begin{array}{l}\mathrm{pO}_{2}, \text { right atrium } \\
\text { torr }\end{array}$} \\
\hline & Control & $\begin{array}{l}\text { Nor- } \\
\text { adrenaline }\end{array}$ & Control & $\begin{array}{l}\text { Nor- } \\
\text { adrenaline }\end{array}$ & Control & $\begin{array}{l}\text { Nor- } \\
\text { adrenaline }\end{array}$ \\
\hline $\begin{array}{l}\text { Expt. } 1 \\
\text { Expt. } 2 \\
\text { Expt. } 3 \\
\text { Expt. } 4 \\
\text { Expt. } 5\end{array}$ & $\begin{array}{l}1.27 \\
1.30 \\
1.06 \\
1.04 \\
1.22\end{array}$ & $\begin{array}{l}0.95 \\
0.91 \\
0.29 \\
0.07 \\
0.06\end{array}$ & $\begin{array}{l}53.7 \\
51.1 \\
59.3 \\
78.5 \\
54.7\end{array}$ & $\begin{array}{r}67.5 \\
58.8 \\
77.8 \\
110.1 \\
79.0\end{array}$ & $\begin{array}{r}12.6 \\
7.9 \\
10.2 \\
6.8 \\
22.2\end{array}$ & $\begin{array}{r}11.9 \\
7.9 \\
5.4 \\
3.5 \\
4.7\end{array}$ \\
\hline
\end{tabular}


Tab. II. Maternal cardiovascular and acid-base status after completion of maternal and fetal surgery for the measurement of placental blood flow and fetal blood gases, as compared to a group of pregnant guinea pigs in which laparotomy was not performed $[14]$. Values are means \pm S.E.

\begin{tabular}{lcc}
\hline & $\begin{array}{l}\text { Experiments } \\
\text { without laparotomy } \\
(\mathrm{N}=14)\end{array}$ & $\begin{array}{l}\text { Maternal and fetal } \\
\text { surgery } \\
(\mathrm{N}=5)\end{array}$ \\
\hline Cardiac output, $\mathrm{ml} / \mathrm{min} / \mathrm{kg}$ & $140.0 \pm 7.6$ & $141.9 \pm 10.0$ \\
Heart rate, beats per min & $20.6 \pm 3.3$ & $226.8 \pm 7.2^{*}$ \\
$\mathrm{Mean}$ arterial blood pressure, torr & $43.4 \pm \pm 2.8$ & $38.8 \pm \pm 3.7$ \\
$\mathrm{pHa}$ & $7.437 \pm 0.012$ & $7.401 \pm 0.018$ \\
$\mathrm{paO}$, torr & $60.9 \pm 3.7$ & $121.8 \pm 25.1^{*}$ \\
$\mathrm{paCO}$, torr & $35.0 \pm 1.1$ & $35.7 \pm 1.9$ \\
Base excess, mmoles/1 & $-0.19 \pm 0.58$ & $-1.76 \pm 1.75$ \\
\hline
\end{tabular}

Significant differences between means: $* \mathrm{p}<0.05 * * \mathrm{p}<0.01$

with polarographic electrodes [11]. However, both experimental data [4] and theoretical considerations [10] suggest that the transplacental flows of oxygen and carbon dioxide are closely interlinked, due to the operation of the HALDANE and BOHR effects. The detailed study of placental gas exchange therefore requires simultaneous measurement of both respiratory gases. Although a combined oxygen and carbon dioxide electrode has been described recently [20], the mass spectrometer remains the most reliable instrument for the measurement of more than one gas, provided that a modern blood gas catheter inlet is used [13].

The feasibility of applying mass spectrometry to measure blood gases in the fetal guinea pig depends foremost upon whether maternal blood gas tensions and the placental blood supply can be maintained during uterine surgery. A comparison has therefore been made with experiments in which regional blood flow was determined without laparotomy (Tab. II). Arterial blood pressure tended to be lower in the present experiments, despite a close similarity in cardiac output. However, maternal placental blood flow $(1.18 \mathrm{ml} /$ $\mathrm{min} / \mathrm{g}$ ) was not significantly different from that in the previous series $(1.30 \mathrm{ml} / \mathrm{min} / \mathrm{g})$. Maternal acid-base status was the same in both groups, whilst oxygenation of the blood was improved in the present experiments by increasing the fraction of oxygen in the inspired air.

Placental gas exchange under the present experimental conditions can be assessed by comparing the composition of umbilical venous blood with that previously found in the guinea pig. Mean umbilical venous $\mathrm{pCO}_{2}$ was 41.7 torr, which compares favourably with published values of $60,61.3$ and 84 torr $[3,18,21]$ and is close to resting levels measured in the fetuses of anaesthetized and conscious sheep [5]. Mean umbilical venous $\mathrm{pO}_{2}$ was 24.5 torr, which is in agreement with values reported earlier [3] and corresponds to the steepest portion of the oxyhaemoglobin dissociation curve for fetal guinea pig blood [2]. The base deficit was, however, larger than previously reported, which may indicate accumulation of lactate due to a less than adequate oxygen supply [17].

In the right atrium, there was a wide variation in $\mathrm{pO}_{2}$ from fetus to fetus. The highest value approached that which we and others [3] have measured in umbilical venous blood, whilst the lowest values approximated to those measured in the umbilical arteries of fetal guinea pigs $[3,9]$. To a certain extent, this variation could depend upon whether the catheter membrane was predominantly in contact with well oxygenated blood from the ductus venosus or with venous blood, as these may be kept apart by streamline flow [19]. Initial $\mathrm{pCO}_{2}$ varied from 51.1 to 59.3 torr in four fetuses and was 78.5 torr in th fifth. The latter value occurred together with a low $\mathrm{pO}_{2}$, indicating fetal distress. As anticipated, an acute reduction in maternal placental blood flow, elicited by the intravenous infusion of noradrenaline, was accompanied by a fall in fetal $\mathrm{pO}_{2}$ and a rise in $\mathrm{pCO}_{2}$. This is in agreement with results obtained 
by conventional analysis of fetal blood samples [1].

These experiments have documented that mass spectrometry can be used to record rapid changes in fetal blood gas tensions. The technique has many potential applications, but is particularly well suited to testing the validity of models of placental gas exchange. Such models are able to predict the adjustments in fetal $\mathrm{pO}_{2}$ and $\mathrm{pCO}_{2}$ that will result from alterations in maternal blood gas tensions and/or placentạl blood flow [10], but take no account of the complex secondary changes in fetal metabolism and circulation. Thus experimental tests of the theoretical predictions ought to include measurements of fetal $\mathrm{pO}_{2}$ and $\mathrm{pCO}_{2}$ in the preregulatory phase, immediately following the initial disturbance in placental gas transfer. In our opinion mass spectrometry is the ideal tool for this purpose.

\section{Summary}

A method is introduced for the continuous and simultaneous measurement of $\mathrm{pO}_{2}$ and $\mathrm{pCO}_{2}$ in fetal blood, using mass spectrometry. This technique alleviates the need for blood sampling and should thus enable the experimental study of placental gas exchange in small mammals. The present report concerns the feasibility of recording changes in blood gas tensions in fetal guinea pigs, brought about by an acute reduction in maternal placental blood flow.

The experiments were performed in late pregnant guinea pigs anaesthetized with pentobarbitone sodium. The head and neck of the fetus were exposed and a stainless steel catheter was advanced from a jugular vein into the right atrium. The tip of the catheter was covered by a polyethylene membrane supported by sintered bronze (Fig. 1) and gases diffusing over the membrane were drawn through the catheter towards the high vacuum chamber of a mass spectrometer. This had been calibrated in vivo for the determination of $\mathrm{pO}_{2}$ and $\mathrm{pCO}_{2}$. Fetal blood gas tensions were measured before, during and after a reduction in placental blood flow caused by intravenous administration of noradrenaline to the mother. The effect of the noradrenaline infusion on placental blood flow and cardiac output was ascertained by the tracer microsphere technique.
Maternal cardiovascular and acid-base status in these experiments was closely similar to that observed in previous studies that did not require laparotomy or fetal surgery. Maternal placental blood flow was $1.18 \mathrm{ml} / \mathrm{min} / \mathrm{g}$ tissue compared to $1.30 \mathrm{ml} / \mathrm{min} / \mathrm{g}$ in the previous studies. Umbilical venous blood from a second fetus in the litter, analyzed by conventional methods, had a $\mathrm{pCO}_{2}$ of 41.7 torr and a $\mathrm{pO}_{2}$ of 24.5 torr, which is comparable with literature values. We conclude that placental gas exchange was satisfactory under the conditions of the experiments, although the base deficit suggested some accumulation of lactate.

In the right atrium of four fetuses, $\mathrm{pCO}_{2}$ measured by mass spectrometry was $51.1-59.3$ torr and $\mathrm{pO}_{2}$ was 7.9-22.2 torr. A fifth fetus seemed to have tolerated the catheterization procedure less well, for its $\mathrm{pCO}_{2}$ was elevated and $\mathrm{pO}_{2}$ depressed. During the noradrenaline infusion, placental blood flow fell by $25 \%-95 \%$. Right atrial $\mathrm{pO}_{2}$ fell rapidly to a new level, whilst $\mathrm{pCO}_{2}$ continued to rise throughout the infusion.

We conclude that mass spectrometry can be used in kinetic studies of fetal blood gases. The technique should be of especial value in studies designed to test models of placental gas exchange.

Keywords: Blood gas analysis, fetal blood, guinea pigs, mass spectrometry, microspheres, norepinephrine, placenta.

\section{Zusammenfassung}

Zur kontinuierlichen Messung von Blutgaswerten beim fetalen Meerschweinchen mit Hilfe der Massenspektrometrie

In der vorliegenden Arbeit stellen wir eine Methode zur kontinuierlichen und simultanen Messung des $\mathrm{pO}_{2}$ und $\mathrm{pCO}_{2}$ im fetalen Blutkreislauf unter Anwendung der Massenspektrometrie vor. $\mathrm{Da}$ diese Methode keine Blutproben erfordert, liegt ihr Vorteil besonders bei kleinen Versuchstieren auf der Hand. Ziel der Arbeit war, die praktische Anwendung der Technik an Meerschweinchenfeten zu demonstrieren, bei denen wir den $\mathrm{pO}_{2}$ und $\mathrm{pCO}_{2}$ nach einer drastischen Minderung der Plazentaperfusion gemessen haben.

Die Experimente wurden an hochträchtigen, mit Pentobarbiton anästhesierten Meerschweinchen durchgefuhrt. Nach Freilegung des fetalen Kopfes und Halses implantier- ten wir einen Stahlkatheter, der mit dem Massenspektrometer verbunden war, über die Vena jugularis in den rechten Vorhof. Die Katheterspitze war mit einer Polyäthylenmembran überzogen, die auf einem porösen Bronzepropfen auflag (Fig. 1). Die Blutgase diffundierten nun durch die Membran zur Ionisationskammer des Massenspektrometers. Die Kalibrierung des Gerätes wurde in vivo vor Beginn der eigentlichen Experimente vorgenommen. Wir haben die Blutgase vor, während und nach der Drosselung der Plazentaperfusion gemessen; diese wurde über die i.v.Infusion von Noradrenalin gesteuert. Die Wirkung des Noradrenalins auf das Herzminutenvolumen des Muttertieren und die Plazentadurchblutung haben wir mittels der Mikrosphärenmethode nachgewiesen.

Die kardiovaskulären Parameter sowie der Säure-BasenStatus waren vergleichbar mit denen früherer Versuchs- 
reihen, bei denen keine Laparotomie und keine fetalchirurgischen Eingriffe erforderlich waren. Die Plazentaperfusion lag mit $1.18 \mathrm{ml} / \mathrm{min} / \mathrm{g}$ etwas niedriger als in früheren Experimenten $(1.30 \mathrm{ml} / \mathrm{min} / \mathrm{g})$. Wir haben auch mit der konventionellen Technik den $\mathrm{pO}_{2}$ und $\mathrm{pCO}_{2}$ im Nabelvenenblut eines benachbarten Feten gemessen, wobei wir Durchschnittswerte von 24.5 Torr $\left(\mathrm{pO}_{2}\right)$ bzw. 41.7 Torr $\left(\mathrm{pCO}_{2}\right)$ fanden. Diese Ergebnisse stimmen mit der Literatur überein. Wir schließen daraus, daß der Gasaustausch in der Plazenta unter unseren Versuchsbedingungen befriedigend funktionierte, obwohl der Basenmangel auf eine Laktatakkumulation hinweist.

Die mit dem Massenspektrometer registrierten Werte betrugen bei vier Feten im rechten Vorhof 51.1-59.3 Torr für den $\mathrm{pCO}_{2}$ und 7.9-22.2 Torr für den $\mathrm{pO}_{2}$. Ein fünfter Fetus hatte einen deutlich erhöhten $\mathrm{pCO}_{2}$ und einen stark erniedrigten $\mathrm{pO}_{2}$, wahrscheinlich als Folge der Katheterisierung. Während der Noradrenalininfusion wurde die Plazentaperfusion zwischen 25 und $95 \%$ reduziert. Gleichzeitig fiel der $\mathrm{pO}_{2}$ im rechten Vorhof rasch auf ein neues Niveau, während die Steigerung des $\mathrm{pCO}_{2}$ mehr kontinuierlich erfolgte.

Wir folgern, daß die Massenspektrometrie zur Verlaufskontrolle von fetalen Blutgasänderungen brauchbar ist. Die Methode wird besonders für Experimente an Modellen, die den Gasaustausch innerhalb der Plazenta untersuchen, geeignet sein.

Schlüsselwörter: Blutgasanalyse, Fetalblut, Massenspektrometrie, Meerschweinchen, Mikrosphären, Noradrenalin, Plazenta.

Résumé

Mesure continue des pressions gazeuses sanguines par spectrometrie de masse chez le foetus de cobaye

Les auteurs proposent une méthode de mesure continue et simultanée de la $\mathrm{pO}_{2}$ et de la $\mathrm{pCO}_{2}$ du sang foetal par spectrométrie de masse. Cette technique soulage de la nécessité de disposer d'échantillons sanguins et permettrait ainsi l'étude expérimentale des échanges gazeux au niveau du placenta chez les petits mammifères. Cet article concerne la possibilité d'enregistrer chez le foetus de cobaye, les modifications des pressions gazeuses sanguines secondaires à une réduction brutale du flux sanguin placentaire maternel.

L'expérimentation a été réalisée chez des cobayes en fin de gestation, anesthésiées au pentobarbitone sodique. Après exposition de la tête et du cou du foetus un cathéter en acier inoxydable est poussé par la veine jugulaire jusqu'à l'oreillette droite. L'extrémité du cathéter est recouverte par une membrane de polyethylène à armature de bronze (Fig. 1), et les gaz ayant diffusés à travers la membrane progressent par le cathéter jusqu'à la chambre à vide poussé d'un spectromètre de masse. L'ensemble a été calibré in vivo pour la détermination de la $\mathrm{pO}_{2}$ et de la $\mathrm{pCO}_{2}$. Les pressions gazeuses sanguines foetales ont été mesurées avant, pendant et après une réduction du flux sanguin placentaire. Ce fluxlà et le débit cardiaque a été établi par la technique des microsphères.

L'état cardiovasculaire maternel et l'équilibre acido- basique au cours de ces expériences a été étroitement semblable à ceux observés lors des études précédentes n'ayant pas nécessité de laparotomie ou de chirurgie foetale. Le flux sanguin placentaire maternel est de $1,18 \mathrm{ml} / \mathrm{min} / \mathrm{g}$ de tissu comparable aux $1,30 \mathrm{ml} / \mathrm{min} / \mathrm{g}$ lors des études antérieures. Le sang veineux ombilical en provenance d'un second foetus de la portée, analysé par des méthodes conventionelles, présente une $\mathrm{pCO}_{2}$ de 41,7 torr et une $\mathrm{pO}_{2}$ de 24,5 torr, ce qui est comparable aux données de la littérature. Les auteurs en concluent que dans les conditions de l'expérimentation les échanges gazeux placentaires sont satisfaisants, bien que le déficit basique suggère une certaine accumulation de lactates.

$\mathrm{Au}$ niveau de l'oreillette droite de quatre foetus, la $\mathrm{pCO}_{2}$ mesurée par spectrométrie de masse est de 51,1-59,3 torr et la $\mathrm{pO}_{2}$ de 7,9-22,2 torr. Un cinquième foetus semble avoir moins bien supporté la technique de cathéterisation, comme en témoigne sa $\mathrm{pCO}_{2}$ élevée et sa $\mathrm{pO}_{2}$ abaissée. Pendant l'injection de noradrenaline, le flux sanguin placentaire chute de $25 \%-95 \%$. La $\mathrm{pO}_{2}$ dans l'oreillette droite chute rapidement vers une nouvelle valeur, tandis que la $\mathrm{pCO}_{2}$ poursuit son élévation durant toute la perfusion.

Les auteurs concluent que la spectrométrie de masse peut être utilisée pour les études cinétiques des gaz sanguins foetaux $\mathrm{La}$ technique devrait prendre un intérêt particulier pour les travaux visant à tester les modèles des échanges gazeux placentaires.

Mots-clés: Analyse des gaz sanguins, cobayes, microsphères, norepinephrine, placenta, sang foetal, spectrométrie de masse.

Acknowledgements: This work was supported by The Danish Medical Research Council.

\section{Bibliography}

[1] ADAMSONS, K., E. MUELLER-HEUBACH, R. E. MYERS: Production of fetal asphyxia in the rhesus monkey by administration of catecholamines to the mother. Amer. J. Obstet. Gynec. 109 (1971) 248

[2] BARTELS, H.: Prenatal Respiration. North-Holland Publishing Company, Amsterdam \& London 1970

[3] BARTELS, H., D. EL YASSIN, W. REINHARDT: Comparative studies of placental gas exchange in guinea pigs, rabbits and goats. Resp. Physiol. 2 (1967) 149
[4] CHANDLER, K. D., A. W. BELL: Effects of maternal exercise on fetal and maternal respiration and nutrient metabolism in the pregnant ewe. J. Dev. Physiol. 3 (1981) 161

[5] COMLINE, R. S., M. SILVER: $\mathrm{pO}_{2}, \mathrm{pCO}_{2}$ and $\mathrm{pH}$ levels in the umbilical and uterine blood of the mare and ewe. J. Physiol., Lond. 209 (1970) 587

J. Perinat. Med. 10 (1982) 
[6] COMLINE, R. S., M. SILVER: A comparative study of blood gas tensions, oxygen affinity and red cell 2,3 DPG concentrations in foetal and maternal blood in the mare, cow and sow. J. Physiol., Lond. 242 (1974) 805

[7] ENDERS, A. C.: A comparative study of the fine structure of the trophoblast in several hemochorial placentas. Amer. J. Anat. 116 (1965) 29

[8] FOËX, P., G. BURT, P. MAYNARD, W. A. RYDER, C. E. W. HAHN: Continuous measurement of blood gases in vivo by mass spectrometry. $\mathrm{Br}$. J. Anaesth. 51 (1979) 999

[9] GHAEMOlSABAHI, A., N. SANANES, M. PANIGEL: La mesure du $\mathrm{pH}$ et de la $\mathrm{pO}_{2}$ du sang artériel et veineux, maternel et ombilical à la fin de la gestation chez le Cobaye. J. Physiol., Paris 60 suppl. 1 (1968) 252

[10] HILL, E. P., G. G. POWER, L. D. LONGO: A mathematical model of carbon dioxide transfer in the placenta and its interaction with oxygen. Amer. J. Physiol. 224 (1973) 283

[11] JANSEN, C. A. M., E. J. KRANE, A. L. THOMAS, N. F. G. BECK, K. C. LOWE, P. JOYCE, M. PARR, P. W. NATHANIELSZ: Continuous variability of fetal $\mathrm{pO}_{2}$ in the chronically catheterized fetal sheep. Amer. J. Obstet. Gynec. 134 (1979) 776

[12] KASTENDIECK, E., W. MOLL: The placental transfer of lactate and bicarbonate in the guineapig. Pflügers Arch. Ges. Physiol. 370 (1977) 165

[13] LUNDSGAARD, J. S., B. JENSEN, J. GR Fast-responding flow-independent blood gas catheter for oxygen measurement. J. Appl. Physiol.: Respirat. Environ. Exercise Physiol. 48 (1980) 376
[14] MÅRTENSSON, L., A.; M. CARTER: Effect of noradrenaline on circulation in the genital tract of early and late pregnant guinea pigs. J. Reprod. Fertil. 66 (in press)

[15] MÅRTENSSON, L., P.-O. B. SJÖQUIST, L. BJELLIN, A. M. CARTER: Myoendothelial and placental blood flow responses to ritodrine infusion in the guinea pig. Amer. J. Obstet. Gynec. 135 (1979) 318

[16] MESCHIA, G., J. R. COTTER, E. L. MAKOWSKI, D. H. BARRON: Simultaneous measurement of uterine and umbilical blood flows and oxygen uptakes. Q. J. Exp. Physiol. 52 (1967) 1

[17] MOLL, W., E. KASTENDIECK: Accumulation and disappearance of lactate in a fetus with a hemochorial placenta. The role of placental transfer and fetal metabolism. J. Perinat. Med. 6 (1978) 246

[18] MORISHIMA, H. O., F. MOYA, A. C. BOSSERS, S. S. DANIEL: Adverse effects of maternal hypocapnea on the newborn guinea pig. Amer. J. Obstet. Gynec. 88 (1964) 524

[19] REUSS, M. L., A. M. RUDOLPH, M. A. HEYMANN: Selective distribution of microspheres injected into the umbilical veins and inferior venae cavae of fetal sheep. Amer. J. Obstet. Gynec. 141 (1981) 427

[20] SEVERINGHAUS, J. W.: A combined transcutaneous $\mathrm{pO}_{2}-\mathrm{pCO}_{2}$ electrode with electrochemical $\mathrm{HCO}_{3}^{-}$stabilization. J. Appl. Physiol.: Respirat. Environ. Exercise Physiol. 51 (1981) 1027

[21] WOODS, L. L., K. L. T̄HORNBURG, J. J. FABER: Transplacental gradients in the guinea pig. Amer. J. Physiol. 235 (1978) H200

Received March 30, 1982. Accepted May 24, 1982.

Dr. J jrgen Grфnlund Department of Physiology Campusvej 55

DK-5230 Odense M Denmark 